\title{
STRATEGI PENYELARASAN PENYUSUNAN APBD DENGAN RPJMD UNTUK MENINGKATKAN PEMBANGUNAN SARANA DAN PRASARANA DI KOTA BEKASI
}

\section{The Alignment Strategy of APBD Planning with RPJMD to Improve Infrastructure Development in Bekasi City}

\author{
Koswara 1, Dedi Budiman Hakim 2, dan Sutara H Kusumaatmadja ${ }^{3}$ \\ 1 Staff Pegawai Negeri Sipil Pemerintah Kota Bekasi. E-mail: mpdipb@hotmail.com \\ 2 Staff Pengajar Departemen Ilmu Ekonomi. Fakultas Ekonomi dan Manajemen - Institut Pertanian Bogor. \\ E-mail: dedihakim@gmail.com \\ ${ }^{3}$ Staff Pengajar Departemen Ekonomi Sumberdaya dan Lingkungan. Fakultas Ekonomi dan Manajemen IPB. \\ E-mail: shkipb@gmail.com
}

\begin{abstract}
Bekasi City is a region which its growth rate of economic and population increase quite rapidly. Thus, supporting facilities and infrastructure development is necessary as it was in one of RPJMD mission 2008-2013. Methods were applied in this research are: 1) Analysis of quality targets of RPJMD program; 2) Analysis of the relevance, efficiency and effectiveness of programs and activities in APBD; 3) Identifing factors influencing the unconformity; 4) Formulating criteria and strategy alternatives through AHP; and 5) Final formulation of the alignment strategy. Result of this research showed some disharmonies both in program and activities planning of APBD and RPJMD caused by factors including: 1) Technology and system in the implementation of planning projects; 2) Endorsement for regional planning officers; 3) Leadership in accelerating the target achievement; 4) Human resources in SKPD; 5) Organization structure and SKPD planning team; also 6) Budget planning and preparation. Above all, strategy of alignment APBD planning with RPJMD has been formulated as follows: 1) Performance improvement of TAPD; 2) Performance improvement through ISO planning; 3) Participation increase in Musrenbang; 4) Communication and commitment of target achievement; 5) Apparatus training and application of functional planner position; 6) Incentive regulation and disincentives implementation; and 7) Draft program completion.
\end{abstract}

Keywords: APBD, Bekasi City, RPJMD, Facilities and Infrastructure Development Strategy

\begin{abstract}
ABSTRAK
Kota Bekasi merupakan kawasan dengan peningkatan laju pertumbuhan ekonomi dan populasi yang cukup tinggi. Oleh karena itu dukungan terkait pengembangan sarana dan prasarana di dalam kota menjadi penting seperti tertuang dalam salah satu misi RPJMD 2008-2013. Metode yang digunakan dalam penelitian ini antara lain: 1) Analisis kualitas sasaran program RPJMD; 2) Analisis relevansi, efesiensi dan perkiraan efektifitas program dan kegiatan dalam APBD; 3) Identifikasi faktor yang mempengaruhi ketidakselarasan; 4) Perumusan kriteria dan alternatif strategi serta penilaian bobot strategi melalui metode AHP serta 5) Perumusan akhir strategi penyelarasan. Berdasarkan hasil penelitian diperoleh gambaran bahwa terdapat beberapa ketidakselarasan dalam perencanaan kegiatan dan program APBD dengan RPJMD yang disebabkan oleh beberapa faktor, meliputi: 1) Teknologi dan sistem dalam pelaksanaan pekerjaan perencanaan; 2) Dukungan kepada aparatur perencana daerah; 3) Pimpinan dalam mendorong percepatan pencapaian sasaran; 4) Sumberdaya manusia di SKPD; 5) Struktur organisasi dan tim perencanaan SKPD serta 6) Perencanaan dan penyusunan anggaran. Dari hasil tersebut diperoleh rumusan strategi sebagai berikut: 1) Peningkatan kinerja TAPD; 2) Peningkatan kinerja dengan ISO perencanaan; 3) Peningkatan partisipasi dalam Musrenbang; 4) Komunikasi dan komitmen pencapaian sasaran; 5) Diklat aparatur dan penerapan jabatan fungsional perencana; 6) Penerapan regulasi insentif dan disinsentif; dan 7) Penyempurnaan rancangan program.
\end{abstract}

Kata kunci: APBD, Kota Bekasi, RPJMD, Strategi Pengembangan Sarana dan Prasarana

Koswara, Dedi Budiman Hakim, dan Sutara Kusumaatmadja Strategi Penyelarasan Penyusunan APBD dengan RPJMD untuk Meningkatkan Pembangunan Sarana dan Prasarana di Kota Bekasi 


\section{PENDAHULUAN}

\section{Latar Belakang}

Pengelolaan keuangan daerah dan anggaran daerah merupakan salah satu aspek penting dalam pemerintahan daerah. Sistem pengelolaan keuangan dimulai dari tahap pelaksanaan hingga pengawasan. Sebagai awal dari sistem pengelolaan keuangan daerah, tahap perencanaan memiliki peranan penting dalam menentukan arah tahapan selanjutnya sehingga kegagalan pada perencanaan akan berdampak pada keseluruhan sistem pengelolaan keuangan daerah (Mardiasmo 2002).

Anggaran Pendapatan dan Belanja Daerah (APBD) merupakan instrumen kebijakan yang utama bagi pemerintah daerah karena menduduki posisi sentral dalam upaya pengembangan kapabilitas dan efektifitas pemerintah daerah (PP Nomor 58/2005). Pada dasarnya, proses penyusunan APBD bertujuan untuk menyelaraskan ekonomi makro dengan sumberdaya yang tersedia secara tepat sesuai kebijakan pemerintah. Berdasarkan Undang-Undang Nomor 25 tahun 2004 tentang Sistem Perencanaan Pembangunan Nasional dan Undang-undang Nomor 32 tahun 2004 Tentang Pemerintahan Daerah, RPJMD atau Rencana Pembangunan Jangka Menengah Daerah merupakan penjabaran dari visi, misi dan program Kepala Daerah terpilih yang penyusunannya berpedoman pada RPJPD dan RTRW Kota Bekasi serta dalam operasionalisasi tahunannya menjadi dasar penyusunan APBD.

Peranan pemerintah dalam proses penyusunan APBD adalah untuk menjamin tercapainya efesiensi penggunaan sumber ekonomi yang tidak dapat dicapai melalui mekasime pasar bebas (Mangkoesoebroto, 2001). Selain itu, upaya peningkatan kualitas perencanaan APBD juga menjadi agenda strategis bagi percepatan peningkatan kesejahteraan rakyat di daerah (Manik, 2008).
Upaya pemerintah Kota Bekasi terkait perbaikan perencanaan dan penyusunan APBD juga dilakukan melalui penerapan beberapa kebijakan daerah. Namun demikian, hasil evaluasi Renstrada Kota Bekasi tahun 2007 menunjukkan bahwa dari 21 sasaran yang terdapat dalam Renstrada 2003-2008, terdapat lima sasaran yang secara nyata tidak tercapai dan 16 sasaran yang diperkirakan dapat tercapai pada akhir periode Renstrada. Kendala lain adalah kurangnya koordinasi antara unit-unit kerja pada pemerintah dalam hal manajemen anggaran.

Mengingat pembangunan sarana dan prasarana kota termasuk dalam kebijakan pembangunan yang tercantum dalam Misi (3) yang juga merupakan sektor dengan pembiayaan terbesar kedua selama pelaksanaan RPJMD Kota Bekasi 2008-2013, maka kajian mengenai strategi penyelarasan penyusunan APBD dengan RPJMD untuk meningkatkan pembangungan sarana dan prasarana di Kota Bekasi perlu dilakukan.

\section{Perumusan Masalah}

Dalam kurun waktu tiga tahun terakhir, sejumlah biaya dalam APBD Kota Bekasi telah dialokasikan untuk berbagai pendanaan berbagai program dan kegiatan. Dari total 8 Misi RPJMP, Misi 1 (penataan sistem layanan pendidikan, kesehatan, dan layanan sosial) mendapat alokasi terbesar dan diikuti oleh Misi (3) (pembangunan sarana dan prasarana) dengan alokasi rata-rata masing-masing sebesar 40,88 persen dan 33,29 persen. Dengan fungsi sebagai pendukung utama aktivitas warga kota, Misi 4 tetap menjadi fokus strategis pembangunan Kota Bekasi.

Apabila dibandingkan dengan kenaikan APBD tahun 2010, proporsi kenaikan Anggaran Belanja untuk Misi (3) menunjukan penurunan. Anggaran belanja pembangunan mengalami kenaikan sebesar 48 persen namun anggaran Misi (3) hanya naik 19,2 persen. Kondisi ini memberikan gambaran bahwa kebijakan anggaran 
tahunan sangat dipengaruhi kebijakan lain. Terdapatnya isu strategis, kebijakan tahunan dan berbagai kepentingan stakeholder seringkali berpengaruh kuat terhadap prioritas dan arah pencapaian sasaran yang telah ditentukan dalam RPJMD, yang pada akhirnya akan mempengaruhi daya dukung (relevan, efesien dan efektif) APBD terhadap pencapaian sasaran RPJMD.

Berdasarkan PP Nomor 58 Tahun

2005, proses penyusunan APBD melibatkan banyak pihak dengan beragam kepentingan, mulai dari SKPD, Pimpinan Daerah, dan DPRD. Permasalahan yang sering kali timbul adalah kurangnya keterpaduan, konsistensi dan sinkronisasi perencanaan, tidak hanya antara aspek perencanaan (RPJMD/Renstrada/RKPD) dan penganggaran, tetapi juga antar SKPD. Kendala lain yaitu kurang adanya Relevansi antara program/kegiatan dengan permasalahan dan peluang yang dihadapi (Manik 2008).

Proses perencanaan anggaran harus dilakukan secara terkoordinasi lintas sektor, daerah, lembaga serta lintas sumber pembiayaan. Tiap tahapan perencanaan harus dilakukan terpadu sejak dari penyusunan kebijakan, perumusan program, penyusunan pembiayaan, monitoring hingga evaluasi (Suhermanto, 2006). Hal ini dikarenakan perencanaan APBD merupakan tahap pertama dalam siklus pengelolaan anggaran sehingga proses ini sangat berpengaruh terhadap keberhasilan pelaksanaan pengelolaan anggaran.

\section{Tujuan Penelitian}

Tujuan utama penelitian ini adalah untuk merumuskan strategi penyelarasan penyusunan APBD dengan RPJMD untuk meningkatkan pembangunan sarana dan prasarana di Kota Bekasi. Untuk menjawab tujuan utama tersebut, maka tujuan spesifik kajian ini adalah:
1. Mengidentifikasi relevansi, efisiensi dan efektifitas program APBD terhadap pencapaian sasaran RPJMD 2008-2013 khususnya dalam Misi (3) (Pembangunan Sarana dan Prasarana Kota)

2. Mengidentifikasi faktor-faktor yang mempengaruhi keselarasan program APBD dengan pencapaian sasaran RPJMD pada Misi (3) mengenai pembangunan sarana dan prasarana kota

\section{TINJAUAN PUSTAKA}

\section{Pengelolaan dan Kinerja Keuangan Daerah}

Mardiasmo (2002) menyampaikan bahwa anggaran publik, termasuk APBD berfungsi sebagai alat untuk perencanaan, pengendalian, kebijakan fiskal, politik, koordinasi, komunikasi, penilaian kerja, motivasi, serta penciptaan ruang publik. Kondisi pendapatan atau penerimaan daerah menggambarkan bagaimana kemampuan keuangan daerah dalam melaksanakan otonomi.

1) Anggaran sebagai alat perencanaan (Planning Tool), yaitu untuk merencanakan tindakan apa yang akan dilakukan pemerintah, berapa biaya yang dibutuhkan dan berapa hasil yang diperoleh dari belanja pemerintah tersebut.

2) Anggaran sebagai alat pengendalian (Control Tool), untuk memonitor kondisi keuangan dan pelaksanaan operasional program dan kegiatan pemerintah.

3) Anggaran sebagai alat kebijakan fiskal (Fiscal Tool), Melalui anggaran publik tersebut dapat diketahui arah kebijakan fiskal pemerintah, sehingga dapat dilakukan prediksi-prediksi dan estimasi ekonomi. Anggaran dapat digunakan untuk mendorong, memfasilitasi dan mengkoordinasikan kegiatan ekonomi masyrakat sehingga mempercepat pertumbuhan ekonomi. 
4) Anggaran sebagai alat politik (Political Tool), sebagai bentuk komitmen eksekutif dan kesepakatan legislatif atas penggunaan dana publik untuk kepentingan tertentu.

5) Anggaran sebagai alat koordinasi dan komunikasi (Coordination and Communication Tool), antar bagian dalam pemerintahan, agar dapat mendeteksi terjadinya inkosistensi suatu unit kerja dalam pencapaian tujuan organisasi.

6) Anggaran sebagai alat penilaian kinerja (Performance Measurement Tool), Kinerja eksekutif akan dinilai berdasarkan pencapaian target anggaran dan efesiensi pelaksanaan anggaran.

7) Anggaran sebagai alat motivasi (Motivation Tool), untuk memotivasi manajer dan stafnya agar bekerja secara ekonomis, efektif dan efesien dalam mencapai target dan tujuan organisasi yang telah ditetapkan.

8) Anggaran dapat juga digunakan sebagai alat untuk menciptakan ruang publik (Public Sphere), dalam arti bahwa proses penyusunan anggaran harus melibatkan seluas mungkin masyarakat melalui proses penjaringan aspirasi masyarakat sebagai dasar perumusan arah dan kebijakan umum anggaran.

Penganggaran atau penyusunan anggaran adalah proses mempersiapkan suatu anggaran yang berisi pernyataan dalam bentuk satuan uang yang merupakan refleksi dari suatu aktivitas dan target kinerja yang hendak dicapai dalam periode waktu tertentu. Oleh karena itu, paradigma baru dalam penyusunan anggaran belanja yaitu sistem penyusunan dan pengelolaan anggaran daerah yang berorientasi pada pencapaian hasil atau kinerja yang juga mencerminkan efisiensi dan efektifitas pelayanan publik (Mardiasmo, 2002).

Penjelasan dari setiap tahapan yang ada dalam siklus manajemen tersebut adalah:
1) Perencanaan Tujuan Dasar dan Sasaran, tujuan dasar dibuat dalam rumusan yang luas dan jangka panjang berkaitan dengan pemenuhan kebutuhan dan peningkatan kesejahteraan masyarakat. Sedangkan sasaran dirumuskan dalam format yang lebih fokus dan mengarah pada bidang-bidang pemerintahan dan pelayanan masyarakat, misalnya Aksi Pengendalian dan pengukuran Penganggaran kesehatan, pendidikan, dan pembangunan infrastruktur. Tujuan dasar harus ditetapkan terlebih dahulu sebagai perencanaan strategik untuk pedoman menyusun perencanaan yang bersifat teknis (perencanaan operasional).

2) Perencanaan Operasional, merupakan penjabaran operasional dari tujuan dasar dan sasaran yang ditetapkan dalam perencanaan strategik, umumnya berupa program dan kegiatan berikut target kinerja yang akan dicapai. Perencanaan operasional dirumuskan dalam perspektif jangka pendek selanjutnya diidentifikasi dan diekspresikan dalam ukuran satuan uang pada tahap penganggaran.

3) Penganggaran, merupakan tahapan aktivitas penting dalam siklus perencanaan dan pengendalaian. Penganggaran adalah proses untuk mempersiapkan suatu anggaran yang berisi pernyataan dalam bentuk satuan uang yang merupakan refleksi dari suatu aktivitas dan target kinerja yang hendak dicapai dalam periode waktu tertentu. Tahap ini menjadi sangat penting karena anggaran yang tidak efektif dan tidak berorientasi pada kinerja akan dapat menggagalkan perencanaan yang telah ditetapkan. Anggaran merupakan managerial plan for action untuk memfasilitasi tercapainya tujuan organisasi.

4) Pengendalaian dan Pengukuran, dilakukan dengan cara membandingkan antara anggaran dengan realisasinya. 
5) Pelaporan, Analisis dan Umpan Balik, penyusunan laporan memuat jumlah pendapatan dan belanja yang dianggarkan dan realisasinya, serta selisih atau perbedaan antara yang direncanakan dengan yang direalisasikan. Selisih tersebut selanjutnya dianalisis untuk mengetahui alasan ataupun penyebab terjadinya. Hasil analisis menjadi dasar untuk feed back tahapan tahapan aktivitas sebelumnya, yang meliputi: revisi perencanaan operasional, revisi anggaran dan/atau aksi. Umpan bailk juga berupa revisi atau modifikasi terhadap tujuan dasar dan sasaran.

Kinerja pengelolaan keuangan daerah diukur berdasarkan indikator tertentu. Solihin (2007) menjelaskan kegunaan indikator kinerja adalah sebagai dasar penilaian kinerja, baik dalam tahap perencanaan (ex-ante), pelaksanaan (ongoing), maupun setelahnya (ex-post). Indikator Kinerja juga dapat dikelompokan sesuai proses pengelolaan anggaran, seperti indikator masukan, proses, keluaran, hasil, manfaat, dan dampak. Namun demikian, pengukuran kinerja di Indonesia masih cenderung dibuat pada tataran input dan output, sedangkan outcome belum sepenuhnya diperhatikan. Hal ini mungkin karena masih terdapat kesulitan untuk menentukan indikator outcome, benefit, dan impact (Mardiasmo, 2002; Mahmudi, 2005 dan Muhammad, 2008). Persyaratan kinerja disebut baik apabila memenuhi kriteria SMART, yaitu Spesific, Measureable, Acceptable, Realistic, dan Timely (Solihin, 2007). Pengukuran kinerja dalam perencanaan Anggaran juga dapat berdasarkan konsep value for money terdiri dari tiga elemen utama yaitu ekonomi, efesiensi dan efektifitas (Mahmudi, 2005).

Kegiatan evaluasi kebijakan dan program pembangunan pada umumnya dilakukan setelah program tersebut selesai dilaksanakan (ex-post evaluation) sedangkan evaluasi program pembangunan yang ada dalam dokumen perencanaan masih jarang dilakukan. Mangkoesoebroto (2001) menyampaikan bahwa inefesiensi anggaran dipengaruhi oleh kecenderungan perilaku birokrat dan legislatif dalam proses penganggaran suatu kegiatan yang dibiayai oleh APBD. Hakim (2009) juga menyatakan bahwa efektifitas dan efisiensi dalam pengelolaan keuangan daerah ditentukan oleh beberapa faktor, diantaranya yaitu sumberdaya struktur organisasi dan teknologi.

Pengukuran kinerja dalam perencanaan Anggaran juga dapat berdasarkan konsep value for money terdiri dari tiga elemen utama yaitu ekonomi, efesiensi dan efektivitas (Mahmudi 2005). Pengukuran Value For Money, meliputi:

1) Ekonomi, yaitu perbandingan antara cost (anggaran) yang disediakan pemda dengan pengadaan input, ukuran yang dihasilkan adalah unit input per rupiah, dari penilaian ekonomi ini dapat diketahui apakah alokasi anggaran dalam APBD dalam menyediakan suatu unit input terjadi pemborosan atau tidak. Dalam aplikasinya, Pemda harus mempunyai pedoman berupa standar biaya untuk belanja input berupa Daftar Satuan Harga Tertinggi.

2) Efisiensi atau produktivitas, yaitu perbandingan antara output per unit input atau dapat juga melakukan perbandingan antara input per unit output. Semakin besar output yang diperoleh dari suatu input maka akan semakin outcome yang sama disebut efesien juga. Efisiensi pada sektor pelayanan masyarakat, adalah suatu kegiatan yang dilakukan dengan baik dengan pengorbanan seminimal mungkin; Suatu kegiatan dikatakan efisien, jika pelaksanaan pekerjaan tersebut telah mencapai sasaran (output) dengan biaya (input) minimal diperoleh hasil (output) yang diinginkan.

3) Efektivitas dilakukan untuk mengukuran tingkat keberhasilan suatu kegiatan atau program yang 

dibuat oleh Pemda, yaitu perbandingan antara outcome per output, ukuran ini untuk menunjukan berhasil atau tidaknya pencapaian tujuan organisasi. Pengukuran efektivitas tidak mungkin bisa dilakuan tanpa mengukur outcome.

\section{Kebijakan Pengelolaan Keuangan Daerah}

Menurut UU Nomor 17 Tahun 2003 tentang Keuangan Negara, dijelaskan bahwa asas-asas Umum Pengelolaan Keuangan Negara ditujukan dalam rangka mendukung terwujudnya good governance dalam penyelenggaraan negara, sehingga pengelolaan keuangan negara perlu diselenggarakan secara profesional, terbuka, dan bertanggung jawab.

APBD adalah rencana keuangan tahunan pemerintahan daerah yang dibahas dan disetujui bersama oleh pemerintah daerah dan DPRD, serta ditetapkan dengan peraturan daerah. Berdasarkan PP Nomor 58/2005 Tentang Pengelolaan Keuangan Daerah, APBD mempunyai fungsi otorisasi, perencanaan, pengawasan, alokasi, dan distribusi. Struktur APBD terdiri atas anggaran pendapatan, anggaran belanja, dan pembiayaan (Undang-Undang Nomor 17 tahun 2003 pasal 16; PP No. 58 tahun 2005 Pasal 20).

\section{Kerangka Pemikiran}

Anggaran Pendapatan dan Belanja Daerah merupakan instrumen kebijakan yang utama bagi pemerintah daerah karena menduduki posisi sentral dalam upaya pengembangan kapabilitas dan efektifitas pemerintah daerah. Kemampuan pengelolaan APBD dimulai dari tahap perencanaan. Dalam RPJMD Kota Bekasi 2003-2013, telah ditetapkan Visi "Bekasi Cerdas, Sehat dan Ihsan" yang dijabarkan dalam tujuh Misi, dimana dalam Misi (3) dinyatakan "Membangun sarana dan prasaran kota yang serasi bagi perikehidupan warga dan pertumbuhan usaha". Kemudian, operasionalisasi Misi (3) diuraikan dalam empat kebijakan dan 26 program pembangunan yang telah ditentukan indikator sasarannya dari setiap program tersebut.

Ruang lingkup penelitian difokuskan pada Misi (3) dan dibatasi hanya pada dua kebijakan, yaitu kebijakan pengembangan sarana dan prasarana perkotaan dan kebijakan pengembangan perhubungan dan transportasi yang masing-masing terdiri dari 9 program pembangunan.

Uraian program dalam kebijakan pengembangan sarana dan prasarana perkotaan meliputi program pengendalian banjir, pembangunan saluran drainase, penyediaan dan pengolahan air bersih, pembangunan, rehabilitasi dan pemeliharaan PJU, pengelolaan RTH, pengelolaan areal pemakaman, peningkatan kesiagaan dan pencegahan bahaya kebakaran, dan pengembangan kinerja pengelolaan persampahan. Sedangkan uraian program dalam kebijakan pengembangan perhubungan dan rransportasi antara lain program pembangunan jalan dan jembatan, rehabilitasi jalan dan jembatan, tanggap darurat jalan dan jembatan, pembangunan sistem informasi jalan dan jembatan, peningkatan pelayanan angkutan, pembangunan prasaranan dan fasilitas perhubungan, peningkatan dan pengamanan lalu lintas, peningkatan kelaikan pengoperasian kendaraan bermotor, serta rehabilitasi dan pemeliharaan prasaranan dan fasilitas LLAJ.

Dari 18 program pembangunan tersebut kemudian diteliti untuk diketahui seberapa besar deviasi kebijakan antara APBD dan RPJMD serta faktor-faktor yang mempengaruhi ketidakselarasan tersebut, kemudian setelah itu dirumuskan strategi untuk penyelarasan penyusunan APBD dengan tujuan Visi/Misi RPJMD agar dapat meningkatkan pembangunan sarana dan prasarana di Kota Bekasi. Strategi ini akan bermanfaat penting 
karena peran Pemerintah Daerah sebagai penyedia barang publik untuk mendukung berbagai aktivitas ekonomi dan sosial

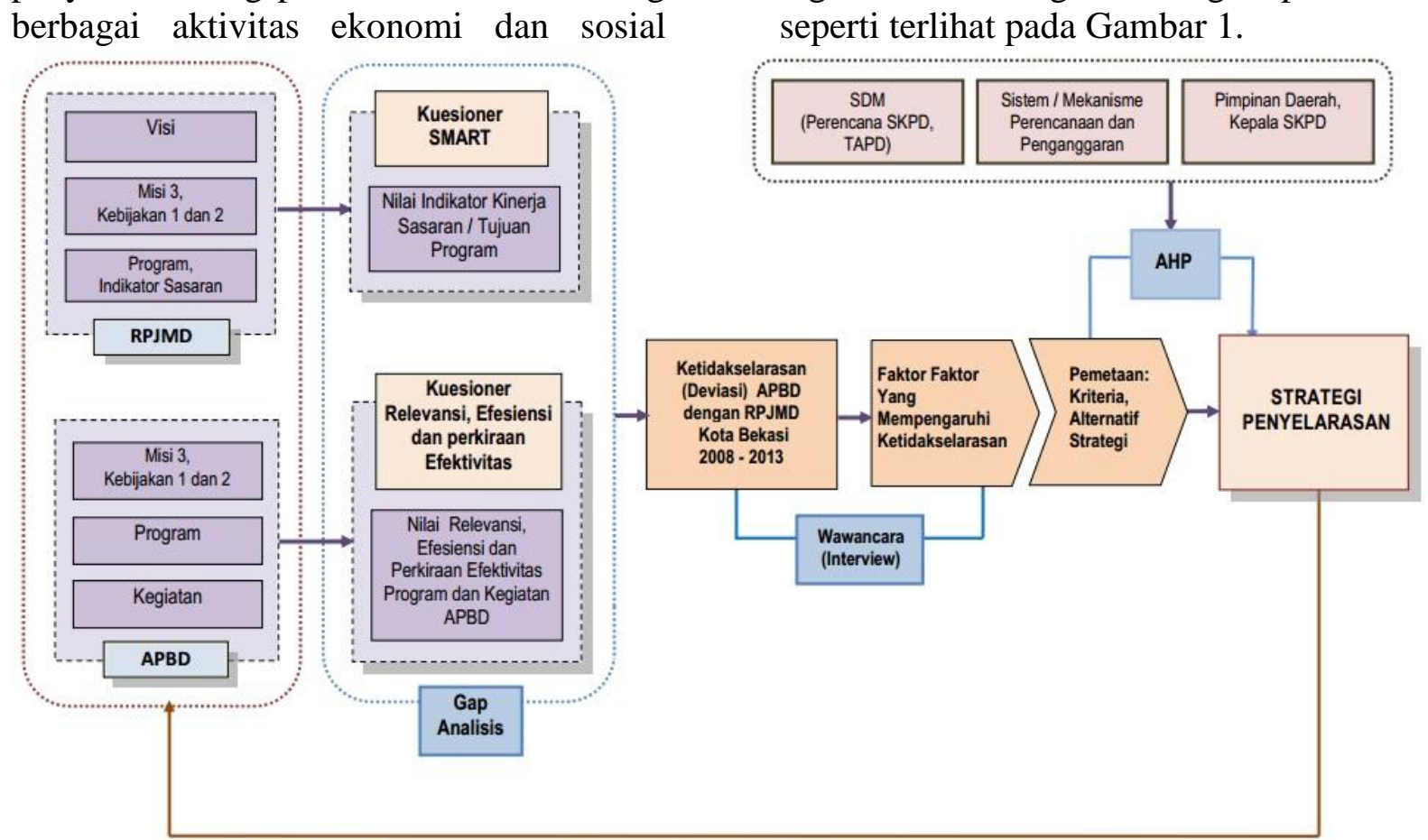

seluruh warga kota. Pemikiran tersebut digambarkan dengan kerangka pemikiran seperti terlihat pada Gambar 1.

Gambar 1. Kerangka Pemikiran

\section{METODE PENELITIAN}

\section{Lokasi dan Waktu Penelitian}

Penelitian ini dilaksanakan di Kota Bekasi, Provinsi Jawa Barat. Pemilihan lokasi kajian didasarkan pada pertimbangan bahwa peneliti bekerja sebagai pegawai negeri sipil di Pemerintah Daerah Kota Bekasi dan bertempat tinggal di Kota Bekasi. Kajian dilaksanakan selama empat bulan, mulai dari Februari 2010 hingga Mei 2010.

\section{Jenis dan Sumber Data}

Untuk kebutuhan analisis, digunakan data sekunder tingkat Kota Bekasi tahun 2008-2010. Jenis data sekunder yang dibutuhkan antara lain data APBD, RPJMD, Renstra (Rencana Strategis) Daerah, Renstra SKPD (Satuan Kerja Perangkat Daerah), Laporan Monev kegiatan pembangunan, data infrastruktur daerah, serta data statistik Kota Bekasi dalam Angka (BPS, 2007; 2008; 2009; 2010). Data tersebut diperoleh dari Bappeda (Badan Perencana Pembangunan Daerah), Dinas Binmarta (Bina Marga dan Tata Air), DPLH (Dinas Pengelolaan Lingkungan Hidup), PJU (Penerangan Jalan Umum), Dinas Perhubungan, Dinas Pertamanan, Dinas Kebersihan, dan BPS (Badan Pusat Statistik).

Selain itu juga digunakan data primer yang merupakan hasil kuesioner dan wawancara dengan stakeholders pembangunan di Kota Bekasi yang terdiri dari unsur Pemerintah Daerah Kota Bekasi (Bappeda, Dinas Binmarta, DPLH, Dinas Kebersihan, Dinas Pertamanan dan PJU, Dinas Perhubungan), DPRD Kota Bekasi dan unsur Akademis (Unisma).

\section{Metode Analisis}

Analisis ini menggunakan metode evaluasi ex-ante evaluation yang mengacu pada RPJMD Kota BekasiTahun 20082013 dan APBD Kota Bekasi 2008-2010. Tahapan analisis yang dilakukan adalah: 
1. Analisis kualitas indikator kinerja sasaran program dalam RPJMD Kota Bekasi 2008-2013 yang dilakukan melalui penilaian indikator SMART (Specific, Measurable, Acceptable, Realistic, dan Time-dependent). Intrepretasi nilai SMART berkisar antara 1-5 dengan nilai 5 yang berarti kinerja tepat sasaran, mudah dievaluasi dan direalisasikan.

2. Analisis relevansi, efesiensi dan perkiraan efektifitas dari program dan kegiatan dalam APBD 2008-2010 dengan menggunakan metode Gap Analysis. Penilaian dilakukan dengan menggunakan sistem skor dengan skala Likert, dengan skor antara 1 (sangat tidak penting/sesuai) hingga 5 (sangat penting/sesuai).

3. Wawancara berdasarkan hasil gap analysis untuk mengidentifikasi faktor-faktor penyebab terjadinya ketidakselarasan antara APBD dengan RPJMD.

4. Pemetaan atau kompilasi data wawancara yang berguna dalam perumusan kriteria dan alternatif strategi.
5. Penilaian bobot strategi melalui metode AHP dengan program Expert Choice ver. 11.5. Prioritas program yang dihasilkan dari proses AHP selanjutnya diuraikan menjadi program kerja yang akan dilaksanakan sesuai kewenangan dari masing masing SKPD yang terlibat.

\section{HASIL DAN PEMBAHASAN}

\section{Pengukuran Relevansi, Efesiensi dan Efektifitas Program APBD Terhadap Pencapaian Sasaran RPJMD Kota Bekasi 2008-2013}

Penilaian Tujuan Sasaran dan Indikator Sasaran

Hasil kuesioner indikator SMART menunjukkan bahwa dari 18 program yang diteliti terdapat lima program yang memiliki kualitas indikator sasaran program dengan nilai dibawah $3(2-2,9)$ yang dapat di interpretasikan bahwa sasaran dapat dipahami tapi sulit dievaluasi dan direalisasikan.

Tabel 1 Penilaian Tujuan (Sasaran dan Indikator Sasaran) dari Program pada Kebijakan (1)

\begin{tabular}{lccc}
\hline \multicolumn{1}{c}{ Kebijakan dan Program } & \multicolumn{2}{c}{ Nilai } \\
Kebijakan (1) Pengembangan sarana dan prasarana perkotaan & & Mak & Rata-rata \\
\hline Program Pengendalian Banjir & 3,20 & 3,80 & 3,60 \\
Program Pembangunan saluran drainase/gorong-gorong & 2,60 & 4,00 & 3,58 \\
Program penyediaan dan pengolahan air bersih & 3,20 & 3,80 & 3,54 \\
Program pembangunan, rehabilitasi dan pemeliharaan prasarana dan & 2,20 & 3,80 & 3,26 \\
sarana PJU & & & \\
Program Pengelolaan ruang terbuka hijau (RTH) & 2,80 & 4,00 & 3,56 \\
Program pengelolaan areal pemakaman & 2,20 & 2,90 & 2,46 \\
Program peningkatan kesiagaan dan pencegahan bahaya kebakaran & 2,20 & 3,20 & 2,47 \\
Program Pengembangan Kinerja Pengelolaan Persampahan & 3,40 & 3,80 & 3,56 \\
\hline Sumber: Hasil Analisis, 2010 & & &
\end{tabular}

Dari Tabel 1, terlihat bahwa dalam Kebijakan (1), terdapat dua program yang memiliki nilai dibawah 3 , yaitu program pengelolaan pemakaman dan program peningkatan kesiagaan dan pencegahan bahaya kebakaran. Apabila dilihat dari pernyataan sasaran dan indikator program dalam RPJMD, kedua program tersebut tidak mencantumkan indikator kuantitaif yang terdefinisi jelas dan target tahunan tidak dinyatakan. 
Tabel 2. Penilaian Tujuan (Sasaran dan Indikator Sasaran) dari Program pada Kebijakan (2)

$$
\text { Kebijakan dan Program }
$$

Nilai

\begin{tabular}{lccc}
\multicolumn{1}{c}{ Kebijakan dan Program } & Min & Mak & Rata-rata \\
\hline Kebijakan( 2) Pengembangan perhubungan dan transportasi & & & \\
Program Pembangunan Jalan dan Jembatan & 3,80 & 4,20 & 4,00 \\
Program rehabilitasi/pemeliharaan Jalan dan Jembatan & 3,00 & 3,80 & 3,63 \\
Program tanggap darurat Jalan dan Jembatan & 2,60 & 3,60 & 3,08 \\
Program Pembangunan sistem informasi/data base jalan dan jembatan & 2,60 & 3,60 & 3,20 \\
Program peningkatan pelayanan angkutan & 2,20 & 2,60 & 2,34 \\
Program Pembangunan Prasarana dan Fasilitas Perhubungan & 3,20 & 3,80 & 3,44 \\
Program peningkatan dan pengamanan lalu lintas & 3,20 & 3,40 & 3,28 \\
Program peningkatan kelaikan pengoperasian kendaraan bermotor & 2,30 & 2,70 & 2,37 \\
Program Rehabilitasi dan Pemeliharaan Prasarana dan Fasilitas LLAJ & 2,20 & 3,00 & 2,74 \\
\hline Sumber: Hail Analisi 2010 & & &
\end{tabular}

Sumber: Hasil Analisis, 2010

Pada kebijakan (2) Pengembangan Perhubungan dan Transportasi terdapat tiga program yang mendapat nilai antara 2-2,9, yaitu Program Peningkatan Pelayanan Angkutan, Program Peningkatan Kelaikan Pengoperasian Kendaraan Bermotor, dan Program Rehabilitasi dan Pemeliharaan Prasarana dan Fasilitas LLAJ.

Berdasarkan hasil penilaian tujuan dengan indikator SMART dapat disimpulkan bahwa pernyataan sasaran dan indikator sasaran dari program dalam Kebijakan (1) Pengembangan sarana dan prasarana perkotaan dan Kebijakan (2) Pengembangan perhubungan dan transportasi yang ada dalam Misi (3) "Membangun sarana dan prasaran kota yang serasi bagi perikehidupan warga dan pertumbuhan usaha", semuanya dapat dipahami, namun ada beberapa program yang memerlukan perbaikan tujuan program agar dapat direalisasikan dengan pembiayaan APBD. Perbaikan yang dimaksud meliputi penyempurnaan uraian dan tahapan pencapaian target, perumusan kembali dan menguji kesesuain indikator sasaran, menyediakan data pendukung sebagai dasar perumusan dan penilaian indikator dan mengkaji kesesuaian kewenangan Pemerintah Daerah dengan lingkup tanggung jawab pelaksanaan program.

Penilaian Relevansi, Efisiensi dan Perkiraan Efektifitas APBD terhadap RPJMD

Berdasarkan hasil penilaian (Tabel 3), program-program dalam Kebijakan Pengembangan Sarana dan Prasarana Perkotaan dan Kebijakan Pengembangan Perhubungan dan Transportasi, Program Pengendalian Banjir, Program Pembangunan Saluran Drainase/GorongGorong dan Program Penyediaan dan Pengolahan Air Bersih memperoleh nilai rata-rata relevansi, effesiensi dan perkiraan efektifitas yang masuk dalam katagori cukup (Relevansi dan Efektifitas = 3-3,55; Efisiensi $=318,48-371,83)$. Hal ini menunjukan bahwa kegiatan dalam program tersebut cukup penting dan effisien untuk mendukung pencapaian tujuan/sasaran RPJMD dengan perkiraan akan memberikan manfaat (outcome) terhadap stakeholders yang cukup sesuai dengan sasaran RPJMD serta dinilai pelaksanaan cukup aman tidak memberikan dampak negatif terhadap stakeholders lain. 
Tabel 3. Hasil Akhir Penilaian REE (Relevasi, Efisiensi dan Perkiraan Efektifitas) Seluruh Responden Terhadap Program APBD 2008-2010

\begin{tabular}{|c|c|c|c|c|}
\hline Kebijakan dan Program & $\begin{array}{c}\text { Releva } \\
\text { nsi }\end{array}$ & Efisiensi & $\begin{array}{c}\text { Efektifi } \\
\text { tas }\end{array}$ & $\begin{array}{c}\text { Daya } \\
\text { Dukung } \\
\text { terhadap } \\
\text { Kebijakan } \\
\end{array}$ \\
\hline \multicolumn{5}{|l|}{ Kebijakan (1) Pengembangan sarana dan prasarana perkotaan } \\
\hline Program Pengendalian Banjir & 3,40 & 371,83 & 3,08 & 107,77 \\
\hline Program Pembangunan saluran drainase/gor & 3,55 & 383,32 & 3,43 & 42,62 \\
\hline Program penyediaan dan pengolahan air bersih & 3,00 & 318,48 & 3,10 & 7,23 \\
\hline $\begin{array}{l}\text { Program pembangunan, rehabilitasi dan pemeliharaan prasarana dan } \\
\text { sarana PJU }\end{array}$ & 3,15 & 352,71 & 2,89 & 68,50 \\
\hline Program Pengelolaan ruang terbuka hijau (RTH) & 2,76 & +3 & 2,8 & 14,05 \\
\hline gelolaan areal p & 2,94 & 293,80 & 2,49 & 7,37 \\
\hline Prog & 3,16 & & 2,54 & 7,42 \\
\hline Program Pengembangan Kinerja Pengelolaan Persampah & 2,92 & 311,03 & 3,30 & 64,97 \\
\hline Total Nilai untuk Kebijakan (1) & & & & 319,93 \\
\hline \multicolumn{5}{|l|}{ Kebijakan( 2) Pengembangan perhubungan dan transportasi } \\
\hline Program Pembangunan Jalan dan Jeml & 3,55 & 354,93 & 3,32 & 20,42 \\
\hline Progr: & 3,06 & 225,47 & 3,30 & 263,03 \\
\hline ggap darurat Jalan dan Jembatan & - & - & - & - \\
\hline Program Pembangunan sistem informasi/data & 2,93 & 324,82 & 3,0 & 11,59 \\
\hline inckatan nelavanan anckutan & 2,90 & 289,84 & 2,84 & 2,41 \\
\hline Progra & 2,81 & 310,76 & 2,99 & 4,20 \\
\hline Program peningkatan dan pengamanan lalu lintas & 2,88 & 295,22 & 2,95 & 4,33 \\
\hline Program peningkatan kelaikan pengoperasian kend & 3,46 & 79,72 & 3,29 & 1,84 \\
\hline Program Rehabilitasi dan Pemeliharaan Prasarana dan Fasilitas LLAJ & 3,30 & 325,51 & 3,01 & 6,51 \\
\hline Total Nilai untuk Kebijakan (2) & & & & 314,33 \\
\hline
\end{tabular}

Sumber: Hasil Analisis, 2010

\section{Jumlah Nilai Daya Dukung} Program terhadap kebijakan, yaitu 314,33 menunjukan secara akumulatif seluruh program cukup mendukung pencapaian sasaran tujuan. Konstribusi dukungan paling tinggi diberikan Program rehabilitasi atau pemeliharaan Jalan dan Jembatan dengan nilai 263,03 (83,7\%) sedangkan program lainnya hanya berkisar antara 0,5-6,5 persen. Ketimpangan nilai daya dukung ini memberikan gambaran bahwa penetapan prioritas belanja dan desain kegiatan pada program selain program rehabilitasi/pemeliharaan jalan kurang tepat. Oleh karena itu, sangat penting bagi Pemerintah Kota Bekasi untuk meninjau kembali desain program, relevansi kegiatan dan penetapan alokasi anggaran agar keseluruhan program dapat memberikan nilai efesiensi dan daya dukung terhadap pencapaian sasaran Kebijakan Pengembangan Perhubungan dan Transportasi.

\section{Faktor Faktor yang Mempengaruhi Keselarasan Program APBD dengan Pencapaian Sasaran RPJMD Kota Bekasi 2008-2013}

Faktor-faktor yang mempengaruhi keselarasan program yaitu Faktor SDM, Faktor Struktur Organisasi dan Tim Perencanaan SKPD, Faktor Teknologi dan Sistem dalam Pelaksanaan Pekerjaan Perencanaan, Faktor Dukungan Kepada Aparatur Perencana dan Faktor Pimpinan, serta Faktor Perencanaan dan Penyusunan Anggaran.

Faktor Sumberdaya Manusia (Tenaga Perencana) di SKPD

Pengukuran faktor ini melalui 8 indikator penilaian yang terkait dengan kemampuan/keahlian SDM tenaga perencana yang dianggap menjadi penyebab terjadinya ketidakselarasan. Secara keseluruhan faktor SDM memperoleh nilai rata-rata 3,83 (dalam skala 5) atau 382,50 (dalam skala 500). 
Hal ini menunjukan faktor ini cukup penting dalam menyebabkan terjadinya ketidakselarasan. Indikator yang paling memberikan konstribusi ketidakselarasan adalah ketidakmampuan aparat perencana dalam menyusun langkah-langkah pelaksanaan rencana yang efisien dan efektif 56,25 (14,7\%) serta kurangnya aparatur untuk mempunyai komitmen dan mampu menyusun instrumen pelaksanaan pembangunan sebesar 57,50 (15\%).

Faktor Struktur Organisasi dan Tim Perencanaan SKPD

Pengukuran faktor ini melalui lima indikator yang berpengaruh terhadap terjadinya ketidakselarasan APBD dan RPJMD. Keseluruhan nilai faktor ini adalah 3,60 atau 360 yang berarti bahwa faktor struktur organisasi dan tim perencana yang ada di SKPD merupakan salah satu faktor yang cukup penting yang mengakibatkan terjadinya ketidakselarasan APBD dengan RPJMD, dimana indikator yang paling banyak pengaruhnya adalah Dinamisnya perubahan personil pejabat perencana di SKPD yang mengganggu kinerja perencanaan $(31,2 \%)$; Kurangnya dukungan dan semangat rekan kerja $(22,8 \%)$; serta adanya Komposisi jabatan struktural dan fungsional dalam bidang perencanaan yang tidak sesuai kebutuhan dan tupoksi SKPD (22\%).

Faktor Teknologi dan Sistem dalam Pelaksanaan Pekerjaan Perencanaan

Nilai konstribusi ketidakselarasan APBD dengan RPJMD terbesar ditemukan pada indikator kurangnya Kultur kinerja $(16,9 \%)$ dan indikator Sistem Kerja/Proses Birokrasi pada Organisasi Perangkat Daerah (14,6\%). Nilai keseluruhan dari faktor ini adalah 390, yang berarti bahwa faktor ini cukup penting sebagai penyebab ketidakselarasan APBD dengan RPJMD Kota Bekasi. Proses penyusunan APBD di 102 Kota Bekasi telah diupayakan untuk mengikuti prosedur sesuai peraturan perundangan, namun formalitas prosedur belum menjamin kualitas substansi perencanaan.

Faktor Dukungan Kepada Aparatur Perencana dan Faktor Pimpinan

Faktor dukungan kepada aparatur perencana dinilai melalui dua indikator yaitu internal dan eksternal, sedangkan penilaian faktor pimpinan diukur melalui empat indikator yang terkait dengan peran pimpinan dalam proses perencanaan. Faktor dukungan kepada aparatur perencana daerah mendapat jumlah nilai 380 yang berarti faktor ini cukup penting sebagai penyebab terjadinya ketidakselarasan, dimana indikator yang paling menjadi penyebabnya adalah kurangnya dukungan dan komitmen Pimpinan SKPD dan Pimpinan Daerah sebesar $(53,9 \%)$.

Faktor Pimpinan juga menjadi faktor penyebab ketidakselarasan dengan jumlah nilai 360. Hal ini dikarenakan kemampuan pimpinan dalam mengelola organisasi publik, merupakan salah satu faktor strategis yang menentukan keberhasilan organisasi. Indikator yang menyebabkan ketidakselarasan adalah kurangnya komitmen pimpinan dalam menjaga kesinambungan proses perencanaan dan mentaati setiap keputusan bersama yang dihasilkan $(29,2 \%)$ dan kurangnya kemampuan pimpinan dalam memberikan arahan dan dukungan kepada Tim Perencana sesuai RPJPD, RPJMD, dan Dokumen Perencanaan (turunan) lainnya $(27,7 \%)$.

Faktor Perencanaan dan Penyusunan Anggaran

Penilaian terhadap faktor ini meliputi lima indikator, dua diantaranya merupakan indikator gabungan dari beberapa sub indikator. Dari penilaian responden terlihat bahwa indikator ketiga (Kesepakatan PPAS disusun berpedoman pada RKPD, kemudian ditetapkan setelah 
dibahas dengan DPRD) memperoleh nilai $42(11,2 \%)$. Nilai yang sama didapat oleh sub indikator $4 \mathrm{c}$ (Penganggaran berbasis kinerja, dimana alokasi anggaran didasarkan pada Target Prestasi Kerja/Keluaran/Hasil Kegiatan/Program; Analisis Standar Biaya; Standar Satuan Harga; dan Standar Pelayanan Minimum) yaitu $42(11,2 \%)$. Nilai kedua indikator tersebut menggambarkan bahwa keduanya merupakan penyebab ketidakselarasan paling dominan.

\section{Perumusan Strategi Penyelarasan Penyusunan APBD dengan RPJMD untuk Meningkatkan Pembangungan Sarana dan Prasarana di Kota Bekasi}

\section{Pemetaan Permasalahan}

Berdasarkan hasil wawancara terhadap narasumber diperoleh gambaran bahwa permasalahan ketidakselarasan perencanaan APBD dengan RPJMD disebabkan oleh beberapa hal yang dapat dikelompokan sebagai berikut: (i) Faktor Sumberdaya Manusia; (ii) Faktor Pimpinan; (iii) Faktor Sistem/Mekanisme dengan strategi pemecahan masalahnya berupa: Diklat Aparatur Perencana dan penerapan Jabatan Fungsional Perencana, Peningkatan Kinerja TAPD Kota Bekasi, Penerapan Regulasi Insentif dan Disinsentif yang Obyektif dan Peningkatan Komunikasi dan Komitmen pencapaian Sasaran RPJMD Kota Bekasi, Peningkatan Kualitas Partisipasi Masyarakat dalam Musrenbang dan Peningkatan Kinerja dengan menerapkan Standar Manajemen ISO dalam kegiatan Perencanaan, dan Penyempurnaan Rancangan Program yang ada dalam APBD maupun RPJMD.

\section{Pemilihan Strategi Prioritas}

Proses ini terdiri dari dua tahapan utama, yaitu perhitungan bobot kriteria dan perhitungan bobot alternatif strategi. Hasil perhitungan bobot kriteria menunjukkan bahwa kriteria Sistem/Mekanisme memperoleh bobot paling tinggi dan memberikan pengaruh paling besar dan penting terhadap penilaian strategi. Hal ini dikarenakan proses perencanaan dan penganggaran dalam keuangan publik tidak terlepas dari sistem birokrasi dan mekanisme serta prosedur yang telah diatur dalam peraturan perundangan. Sedangkan hasil analisis perhitungan bobot alternatif strategi menunjukkan bahwa dari sudut pandang Sistem atau Mekanisme, Peningkatan Kinerja TAPD meraih bobot alternatif strategi sebesar 0,274. Hal ini dapat diartikan bahwa strategi ini sangat penting untuk melakukan penyelarasan APBD dengan RPJMD Kota Bekasi.

Selanjutnya, baik dari penilaian terhadap kriteria pimpinan maupun kriteria SDM, alternatif strategi Peningkatan Kinerja TAPD dan Peningkatan Kinerja dengan menerapkan Standar Manajemen ISO dalam kegiatan Perencanaan menempati prioritas 1 dan 2 dengan bobot 0,257 dan 0,71 untuk strategi Peningkatan Kinerja TAPD serta 0,250 dan 0,245 untuk Peningkatan Kinerja dengan menerapkan Standar Manajemen ISO dalam kegiatan Perencanaan.

Bobot Alternatif Strategi terhadap Tujuan

Hasil akhir penilaian AHP menunjukan bahwa strategi Peningkatan Kinerja TAPD $(0,271)$ merupakan prioritas pertama dalam mencapai tujuan penyelarasan APBD dengan RPJMD, diikuti oleh Strategi Peningkatan Kinerja dengan ISO Perencanaan $(0,247)$, strategi Peningkatan Partisipasi dalam Musrenbang $(0,138)$, Strategi Komunikasi dan Komitmen Pencapaian Sasaran (0,117), Strategi Diklat Aparatur dan Penerapan Jabatan fungsional Perencana (0,089), Strategi Penerapan Regulasi Insentif dan Disinsentif $(0,074)$, dan Penyempurnaan Rancangan Program $(0,065)$. Detail hasil analisis dapat dilihat pada Gambar 2. 


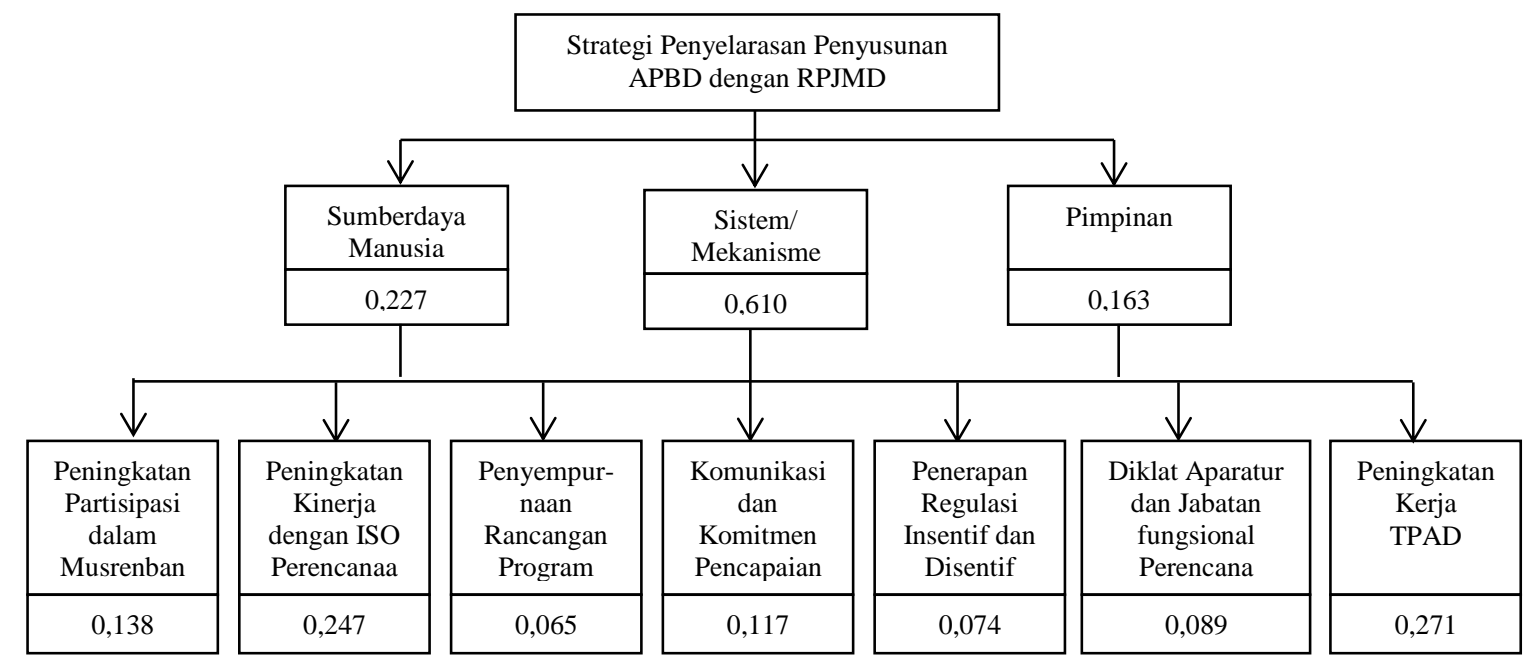

Gambar 2. Hirarki Bobot Akhir Strategi Penyelarasan APBD dengan RPJMD untuk Meningkatkan Pembangunan Sarana dan Prasarana Kota Bekasi

\section{Rancangan Program Penyelarasan APBD dengan RPJMD}

Berdasarkan hasil analisis yang dilakukan, maka dirancang programprogram yang bertujuan untuk menyelaraskan APBD dengan RPJMD, yaitu Program Peningkatan Kinerja TAPD, Program Peningkatan Kinerja dengan ISO Perencanaan, Peningkatan Partisipasi dalam Musrenbang, Program Komunikasi dan Komitmen Pencapaian Sasaran, Program Diklat Aparatur dan Penerapan Jabatan fungsional Perencana, Program Penerapan Regulasi Insentif dan Disinsentif, serta Program Penyempurnaan Rancangan Program yang ada dalam APBD maupun RPJMD.

\section{KESIMPULAN DAN SARAN}

\section{Kesimpulan}

1. Hasil analisis relevansi, efisiensi dan efektifitas program APBD terhadap pencapaian sasaran RPJMD 20082013 khususnya dalam Misi (3) Pembangunan Sarana dan Prasarana Kota menunjukkan bahwa dari 18 program yang dievaluasi terdapat 11 program yang secara nyata memiliki nilai kurang dari standar penilaian, yaitu program pembangunan, rehabilitasi, pemeliharaan dan peningkatan pelayanan prasarana dan sarana PJU; program pengelolaan ruang terbuka hijau (RTH); program pengelolaan areal pemakaman; program peningkatan kesiagaan dan pencegahan bahaya kebakaran; program pengembangan kinerja pengelolaan persampahan; program rehabilitasi/pemeliharaan jalan dan jembatan; program pembangunan sistem informasi/data base jalan dan jembatan; program peningkatan pelayanan angkutan; program pembangunan prasarana dan fasilitas perhubungan; program peningkatan dan pengamanan lalu lintas; program peningkatan kelaikan pengoperasian kendaraan bermotor; serta program rehabilitasi dan pemeliharaan prasarana dan fasilitas LLAJ.

2. Hasil identifikasi faktor-faktor yang mempengaruhi ketidakselarasan program APBD dengan pencapaian sasaran RPJMD pada Misi (3) pembangunan sarana dan prasarana kota menunjukkan bahwa terdapat enam faktor utama penyebeb ketidakselarasan dalam penyusunan yang meliputi: faktor teknologi dan 
sistem dalam pelaksanaan pekerjaan perencanaan; faktor dukungan kepada aparatur perencana daerah; faktor pimpinan dalam mendorong percepatan pencapaian sasaran/tujuan; faktor sumberdaya manusia (tenaga perencana) di SKPD; faktor struktur organisasi dan tim perencanaan SKPD; serta faktor perencanaan dan penyusunan anggaran.

\section{Saran}

Pelaksanaan strategi penyelarasan penyusunan APBD terhadap RPJMD Kota Bekasi 2008-2013 dapat dilakukan melalui serangkaian rekomendasi kegiatan, antara lain:

1. Rekomendasi kegiatan dalam kerangka regulasi penyelarasan penyusunan APBD terhadap RPJMD yang terdiri dari tiga kegiatan utama (pembuatan Perda, Perwal, Juknis, dan Pedoman, perkuatan fungsi dan keterlibatan pimpinan dalam kegiatan perencanaan, serta perbaikan atau penyempurnaan Program RPJMD dan APBD).

2. Rekomendasi kegiatan dalam kerangka investasi untuk penyelarasan penyusunan APBD terhadap RPJMD yang meliputi tiga kegiatan utama, yaitu: 1). Penyediaan sarana prasarana kerja yang memadai untuk TAPD dan unit perencana di SKPD; 2). Diklat yang terdiri dari perencanaan strategis, pembangunan, teknis, manajemen, dan mutu serta 3). Jasa konsultan.

\section{DAFTAR PUSTAKA}

[BPS] Badan Pusat Statistik. 2007. Kota Bekasi Dalam Angka 2006. Badan Pusat Statistik Kota Bekasi. 2008. Kota

Bekasi Dalam Angka 2007. Badan Pusat Statistik Kota Bekasi. 2009. Kota Bekasi Dalam Angka 2008. Badan Pusat Statistik Kota Bekasi. . 2010. Kota

Bekasi Dalam Angka 2009. Badan Pusat Statistik Kota Bekasi.

Hakim, D.B. 2009. Manajemen Keuangan dan Investasi Daerah. Manajemen Pembangunan Daerah. Sekolah Pasca Sarjana. Bogor: Institut Pertanian Bogor.

Mahmudi. 2005. Manajemen Kinerja Sektor Publik. Yogyakarta: UPP STIM YKPN.

Mangkoesoebroto, Guritno. 2001. Ekonomi Publik. Edisi 3. Yogyakarta: BPFE-Yogyakarta.

Manik, Rusman R. 2008. Swadaya Masyarakat. 15 April 2008

Mardiasmo. 2002. Otonomi dan Manajemen Keuangan Daerah. Yogyakarta: ANDI Offset.

Muhamad, Fadel. 2008. Reinventing Local Goverment - Pengalaman dari Daerah. Jakarta: Kompas Gramedia.

Solihin, H Dadang. 2007. Semiloka DPRD Kabupaten Bekasi, Bandung, 24 Mei 2007.

Suhermanto, Herry. 2006. Prinsip Dasar Perencanaan. Paparan Sosialisasi Perencanaan. Bappenas Jakarta 